\title{
CXCL8 wt Allele
}

National Cancer Institute

\section{Source}

National Cancer Institute. CXCL8 wt Allele. NCI Thesaurus. Code C50942.

Human CXCL8 wild-type allele is located within 4q13-q21 and is approximately $3 \mathrm{~kb}$ in length. This allele, which encodes interleukin- 8 protein, is involved in chemotaxis and angiogenesis. 